\title{
Quran 3+9x6 And 72 Stupas from Bibakkah as Baka Queen with Constant 12 Worship on Hahslm 472319 Universe in Covid Economic Period
}

\author{
$1^{\text {st }}$ Roikhan $\mathrm{MA}^{1}, 2^{\text {nd }}$ Dita Nur Amanda ${ }^{2}$ \\ \{roikhan.ma@uinjkt.ac.id ${ }^{1}$, ditanuramanda@gmail.com ${ }^{2}$ \} \\ UIN Syarif Hidayatullah Jakarta ${ }^{1,2}$
}

\begin{abstract}
The research aims to analyze the reflexivity of the Quran 3:96 with 72 stupas from the word Bibakkah as Baka Queen in the approach of constant 12 and hahslm 472319 in a period of covid economic. The number 72 is found in physics and worship. The objects of this study are the Baka Queen and Borobudur and Holy Book. This research is a desk study by referring to book, journals, Holy Book, and media internet. The methodology used is descriptive analysis. The methods are similarity and reflexivity with the benchmark of Hahslm and constant number. The results are that Quran Surah Ali Imran [3]:96 has the same calculation with 72 from $(3+9) \times 6=72$. It shows 72 stupas that related to the name of Bibakkah as Baka Queen. This letter explained the old house has been moved (put) and built by Baka Queen.
\end{abstract}

Keywords: Quran, stupa, Baka, queen, worship.

\section{Introduction}

National civilization can be traced to historical relics of buildings or stone carvings in sheets. The universe can give clues to the meaning of creating objects for worship. God also gave instructions that the symbols of creation in various forms with the meaning of worship. The existence of historic buildings can be copied to find the connections universe as the symbol of worship. Among them are the patterns in the 72 stupas which are located in the Borobudur immortal region and the remaining 12 as a symbol of the blueprint worship [1].

The immortal queen's ascent can be linked to spirituality. Research on the interconnecting of old buildings suggests Islamic archaeology is limited. The research and writing of historical buildings go far beyond materialism. Limited to research the history of buildings with economic approach and religiosity.

Relics found in the Borobudur underworld region are products of the past that can be developed to promote the welfare of the people. The cultural product consists of knowledge of the brick temple. The brick temple is a process of knowledge of the past that can be drawn to the present [2].

To this day, the archaeological system of the Borobudur afterlife has developed concepts based on a religious economic community by involving people in various activities. Involve the public in various activities. This society's involvement will transfer science into its forms of preservation and use. 
An area that has archaeological potential is going to be a central economy. Growing up, small enterprises from past products reflect the distinctive or superior products of the surrounding areas [3].

Currently, the government has implemented a Covid vaccination program in Indonesia which has been started since January 2021 for priority groups, such as health workers, public service providers, to the elderly. The Ministry of Health (Kemenkes) predicts that Covid vaccination can increase the growth of the economy.

\section{Methodology}

The scope of this research is QS. Ali Imran [3]: 96, the Ratu Baka palace area in Yogyakarta, the Borobudur stupa in Magelang, the wave pattern by 2 splits, and the function of the plural prayer. Several objects of study that differ in field of study are combined in this research, then combined into a single unit to show the similarity of patterns between objects in different fields of study.

The research approach is carried out by using the Hahalm formula 472319 as a complex reference. This formula is a derivative of QS. Al-Hijr [15]: 87. This complex reference is a benchmark for the existence of an object that becomes a reflection or reflexivity within the framework of science.

Meanwhile, as a reference for the simple model, constant 12 (R-12) is used, which is named after its inventor, Roikhan. In the concept of worship, this R-12 is a plural prayer concept which consists of one part of the prayer that cannot be pluralized and two parts of the prayer that can be pluralized.

The methodology used in this research is comparative analysis. The reference used as the main description in the form of a simple formula which is the reference for the model is R-12 which was created by God in QS. At-Taubah [9]: 36. Meanwhile, objects with more complexity will be approached with the Hahslm 472319 (R-47) formula narrated in QS. Al-Hijr [15]:87 and formulated by Roikhan. So, when it is mentioned as R-12, it is connoted as a constant 12 . Meanwhile, if it is stated as R-47, it will refer to the Hahslm formula 472319 [9].

The object of this research will be the similarity of the model with the R-12 and R-47. This is done to analyze the function and existence of the presence of numerical elements or structures in the object.

Elements in objects are elements between objects that will have boundaries and relationships. The relationship between these objects must be in accordance with the Dynivity rule which is a causality hierarchy between objects that have coordinates and directions. The Dynivity method has a minimum standard of interrelated variables that must consist of 3 variables. Each of these variables can be composed of groupings or indeed separated structurally.

These three methods are carried out to ensure the similarity of the object of this study. With the fulfillment of this method in the object of study, it can be confirmed that the object is the same object and has conformity with R-12 and R-47. 


\subsection{Theoretical basis}

\subsubsection{Historical landmarks}

Abu Fatiah researched a futuristic review of prophecies from the prophet (prophet) concerning the latter-day lands. Studies of the links of old buildings to Islamic values such as temples or stupas become models of development that Islam also has a futuristic dimension. Similar to economists who do studies and predictions about future trends; What will become an admiration for many, or what product will be expected to be consumer possession, or what styles and values will be widely held by humans. Hasan ambary also tried to settle Islamic archaeology as an example of archaeological contact with other disciplines (Milosevic) [4].

The study of Islam, islamology, the institution of Islam, the history of Islamic culture forms islamological archeology divided into epigraph studies, philology as ancient text studies, architecture as sacred buildings, settlement as urban patterns, iconography as ICONS and sculpture, anthropology as culture, sociology as message history, and numismatics as currency.

Linking the studies of Islam, archaeology, and archaeology is the subject of a new study that can tentatively be called "archaeo-islamology" or Islamic archaeology. The approach through these thematic studies does not mean "the elimination" of the encoding of the history of Islamic culture in the temporal dimension. So that it can track the history and culture of Indonesian Islam [5].

A cultural significance-oriented historical building in futuristic Islam - the establishment and cultural heritage - can be traced back to the beginning and key themes in the immortal stupa building with a guide to the holy scriptures.

\subsubsection{Physics}

Quantum physics begins with a phenomenon interference with danger and waves. The waves that arise from 2 crevices form a circle resulting from the meeting of large waves from those two dots. A small circle harmoniously forms seven circles and seven hedges. The pattern formed is the sequel to two crevices, thus forming seven circles. The digits that appear could be a pattern of 72 (seven pieces two) or 27 (twenty-seven) depending on the context of science being analyzed. Because the double digits are 2 and 7 or are made up of 7 and $2[6]$.

\subsubsection{Baka queen palace}

Scientists have uncovered evidence that saba's land or the region of the immortal queen once existed. The evidence is ma "rib dam or arim dam. This dam is told by the historian of Arabia in several areas. Al-Hamdani in his book entitled wasfu jaziratil Arabia. Hamdani explains that the ma dam "rib is one of the evidence that saba's land" of the Quran is in southern Yemen [7].

Baka Borobudur is was built from nearly millions of volcanic boulders mined from the remnants of a volcanic eruption not far from the site. This temple has been the subject of various theories trying to explain its purpose and even its spiritual connection. The exact purpose of this temple is not clear, because it is not a temple and not a stupa. The author's prediction is about the symbol of Islam. 


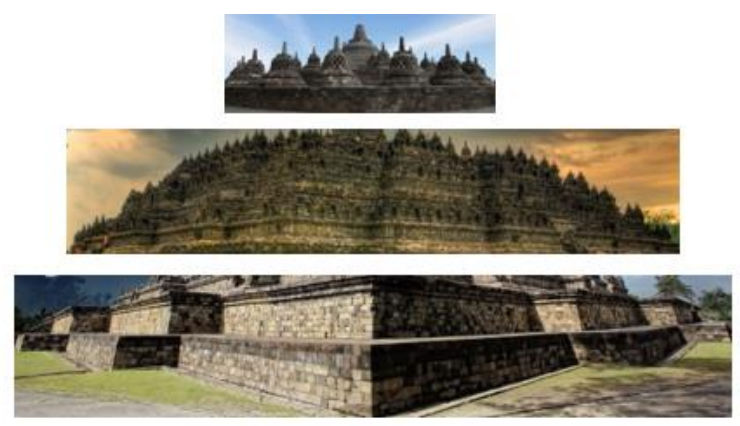

Fig. 1. Borobudur upper-middle base.

The structure of the Borobudur Temple consists of three parts: basic, middle, and top. The basic architecture is the basic identifier structure or as a dependent variant. With a 12 partitioned quadrilateral grid pattern which has similarities to the Turtle pattern [8].

\section{Result and Discussion}

The palace of the Baka Queen (Java: Ratu Baka) is the site of a complex number of remains located about $3 \mathrm{~km}(2 \mathrm{mi})$ south of the Prambanan temple complex, $18 \mathrm{~km}(8 \mathrm{mils})$ of Yogyakarta, or $50 \mathrm{~km} \mathrm{(30} \mathrm{mi)} \mathrm{sw} \mathrm{of} \mathrm{the} \mathrm{city} \mathrm{of} \mathrm{Solo,} \mathrm{Central} \mathrm{Java,} \mathrm{Indonesia.} \mathrm{The} \mathrm{site} \mathrm{of} \mathrm{the}$ queen of Baka is situated on a hill 800 feet [196 m] from sea level. The overall area of the complex is about 25 ha [10].

The site displays attributes as a staging area or a residential site, but the exact function is not known. Queen Baka was thought to have been used in the 8th century during wswan sailendra (rakai panangkaran) of the medang kingdom (Mataram Kingdom). Judging from the construction construction construction pattern, it is believed to be a former Keraton (King's Palace). This view is based on the fact that this complex is not a temple or a building of a religious nature but is a fortified palace with evidence of leftover fort walls and dry moats as a bulwark. Residents' remains were also found in the vicinity of the site.

The Baka Queen was first reported by Van Boeckholzt in 1790, claiming the ruins of antiquities on the hill of the queen of the underworld. The hill itself is a substation of the sewu mountain system, extending from Yogyakarta to the great Tulungian region.

The layout of the complete of the Baka Queen's keraton complex consists of buildings the main arch, the field, the burning temples, the carpeted pool, and the paseban. The southeast covers the floor structure, the arch, the pendopo batur, the prong batur, the 3 temples miniature, the surrounding wall of a complex of judging, the two pools, and the ruins of the stupa. From the palace gate to the center of the front, the main section, are two lofty arches, which consist of two layers. The first arch had three doors while the second had five.

In the Quran, there is an equation 72 from the combination of the letter-number (3) and the verse number (96) with equations are $(3+9) \times 2$ equal to 72 . With the similarity method, the equivalence between the number 72 and verse 396 will be obtained. This means that 72 stupas are located in the verse that stores about 72 encryption and password of owner name of stupa building. 
In verse 3.96 listed the word, Bibakkah is articulated as at Bakkah or Kabah. This articulation leads to the landmark of the Kabah rather than the name Bakkah because the previous sentence and after it contains the Hajj. Islamic scholars interpret the verse that is in the middle between the Hajj verses will still point to the landmarks of the Hajj. The content of the verse that reads Bakkah with simple logic will be likened to the reversed word, such as Kabah. But, there is a reversed language communication used. Some people said about the word of Monas, become Sanom. So the change in the word Bakkah should be the word Hakkab or Akkab. With the consideration of the causality of the sentence before and after it, the word Bakkah turns into Kabah. This adapts to the existing landmarks in the Hajj environment.

There are several options for understanding the word Bakkah, as Kabah, Hakkab, or Bakkah. The word Bakkah can be referred to a person's name as Baka. With the addition of the letter $\mathrm{h}$ (ha, Arabic) as ta marbutoh, it can be personified as a female Baka. In Indonesia there is a very legendary female Baka name, there is Ratu Baka (Queen Baka).

The mention of people's names in the Quran indicates an above-average level of ability. Ratu Baka is the one and only person from Indonesia that is written in the Quran. The location of Ratu Baka's existence is in Yogyakarta, Indonesia, which is displayed empty kingdom of Ratu Baka. This emptiness means that once there had been greatness and landmarks which were then moved to another location.

By synchronizing the mathematics of the Bakkah 3.96 verse which amounts to 72 , logically the causality of the owner of the 72 stupas is Ratu Baka. This is summarized in 1 verse which means 72 and Bakkah. Evidence in the field that Ratu Baka was the owner of 72 stupas before being moved, can be seen from the remains of 1 stupa left in the Ratu Baka area. One stupa is identical to the form of 72 stupas that have been moved to another place.

Seventy-two stupas had stored the technological sophistication that has been found in the era before the prophet Muhammad. This is shown in the phrase the word of the beginning house (awalun baiti, Arabic) which can be interpreted that before the revelation of verse 3.96 or before the era of the prophet Muhammad, there has been the first house that had been built around humans.

The words moved (wudhia, Arabic) also strengthen the evidence that the original house was moved. The word moved comes from the word put which is elaborated into a phrase of can be moved to another place. So, 72 stupas as the first house had been belonging to Ratu Baka as modern technology at ancient times have been moved to another place. The existence of these 72 stupas holds the meaning of quantum physics in the current Covid economic era. With the global pandemic, the intensity of the use of interference technology is getting higher. With the economic crisis due to Covid, efficiency is a must in various sectors, including the implementation of Work From Home (WFH) and online learning.

Physical science has only just been able to understand the interference that occurs in these decades. Researchers can identify the most advanced technology in communicating over the air and devices on mobile phones. This interference is formed from 7 hexagons originating from the overlay of water waves that are clapped by 2 split hands. This 72 pattern can only be solved as interference quantum physics just in some decades, even though Ratu Baka had built an initial house in the form of 72 stupas a long time ago.

Technology 72 can be found at Ratu Baka Stupa, mobile phone communication, double split water wave, and double split light gun. So there is a connection between the 72 Baka stupas with the water waves that can be found in the surrounding environment. The right-hand pats the water and simultaneously the left hand also taps the water, so there appear water waves form from 2 points. The cross-section between 2 water waves will meet each other and overlap each other to form a small column in a 7-column patterned system or dynivity. 
Apart from the development of 72 encryption, there are also 12 codes stored from this Bakkah verse with a combination of $(-3)+9+6$ equal to 12 . Twelve is a combination of balance numbers 6 , where $12 \times 6$ equals 72 , so there are triple balancing numbers, apart from that there are 12 beside Allah in another verse. This shows that the number 12 is a constant. Twelve also refers to the meaning of worship in the form of congregational prayers, according to 1 is the dawn prayer which cannot be plural, and 2 groups of prayers that can be plurals, such as the salat zuhur asar and salat magrib isa. So, in addition to 72 are showing the quantum meaning, it turns out that 72 also holds the meaning of salat as worship constant.

A stupa identified 72 things over the Borobudur. Some research indicates that the stupa in the Baka Queen palace is more powerful in describing its sculptures of stupa than the one in the blur of Borobudur. This means that 72 stupas in the Borobudur were transfers from 72 stupas who had originally been in Baka Queen's palace.

The analysis of the ownership of the 72 stupas is based on the written qs. Ali Imran [3]:19 directly refers to the name of the person in the area Baka Queen.

Table 1. Translated from Arabic to English and Indonesian.

\begin{tabular}{llll}
\hline No & Arab & English & Indonesian \\
\hline 1 & ب. & $\begin{array}{l}\text { By Bakkah } \\
\text { (woman) }\end{array}$ & $\begin{array}{l}\text { Oleh Bakah } \\
\text { (perempuan) }\end{array}$ \\
& & By Bakka (man) & Oleh Baka (laki) \\
2 & Bakka (name) & Baka (nama) \\
3 & By (conjunction) & Oleh (kata \\
4 & + & penghubung) & Ta marbutoh \\
& & Ta marbutoh & (perempuan) \\
\hline
\end{tabular}

Source: Analysis, 2021

In QS. Ali Imran [3]: 96 it says that the first buildings that were laid into humans were evil. From the table and the meaning of which it boils down to the context that the owner of that early building is the devil who has significance by the Baka Queen. Bi means by, whereas afterlife is a person's name. In Arabic, the unnamed bakka indicates the man's name is baka. The big "h" means the girl's name is bkah. So the early 72 stupas were the queen bakka. Seventy-two stupas are documented in the letter number and the verse number is 3 letter number, 96 verse number. In combination, Numbers would be 396 which is $(3+9) \times 6$ or $12 \times 6=72$. The 72 stupas according to this verse belong to Baka Queen.

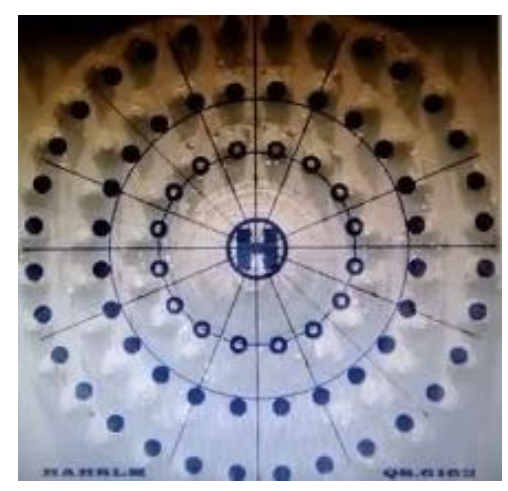




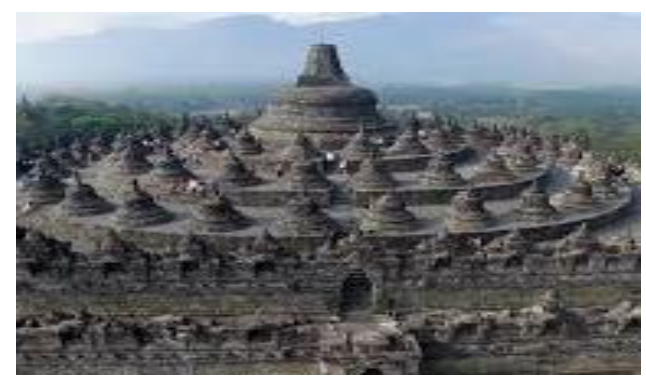

Fig. 2. Upper Borobudur Architecture.

Research on Borobudur Temple that has been carried out today focuses more on mathematical concepts as a result of designing buildings, measuring, making patterns, and how to relate these mathematical physics concepts to mathematics learning [11].

The concept of mathematical physics at Borobudur Temple is shown by the shape of the building structure resembling the concept of flat and spatial shapes in mathematics. The essence of Borobudur Temple is a stupa. When viewed from above, it is in the form of a large mandala pattern, which is an arrangement of patterns consisting of squares and concentric circles that symbolize the universe. The design concept of the Borobudur Temple can be related to Euclidean Geometry. The building structure of Borobudur Temple consists of two main forms, namely circle, and square [12].

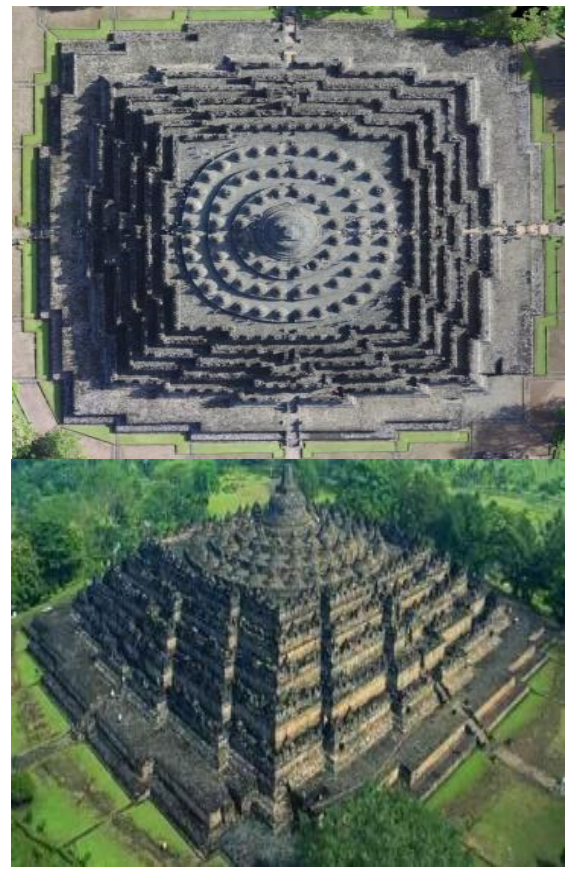

Fig. 3. Central borobudur architecture.

Research on Borobudur Temple states that there is a relationship between teachings, philosophy, and physics concepts that shape the building of Borobodur Temple into a 
phenomenal megastructure. The Borobudur Temple building is the realization of a structured, unique, and beautiful physics concept. In every part of the temple structure, there are moral and philosophical messages that describe the teachings, culture, and realities of life during its construction. The concept of Hahslm, teachings, and philosophy becomes a unity that cannot be separated from Borobudur Temple. This relationship inspires an understanding of the kanyum interference as an orchestra of life, where all the concepts are united in ethnomathematics.

The interference that occurs in the electron shot can be carried out in 2 or more slots so that it can be said that interference can occur with the least 2 slots. Interference can also be done with 3 slots or 4 slots [13].

With the enlargement of the water waves, there is an impact and overlaps with each other. The overlapping wave lines from 2 water point sources that meet each other in the middle and slightly upward turn out to form a 6-sided pattern.

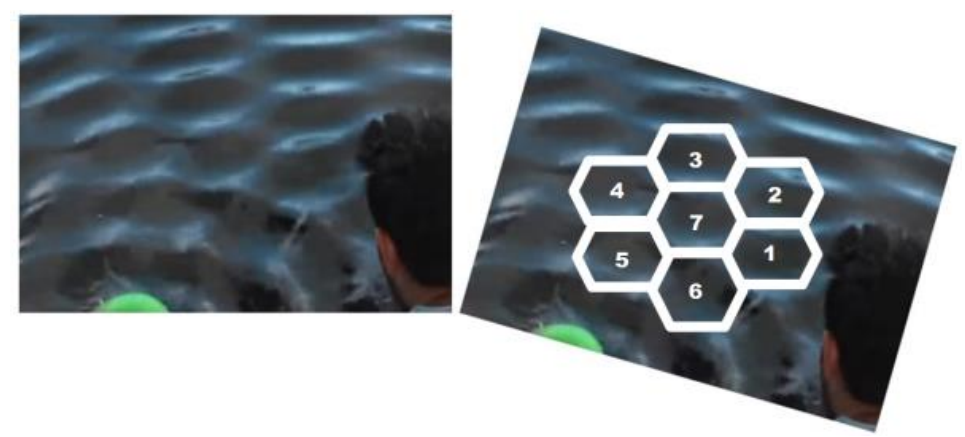

Fig. 4. Quantum interference of water hahslm.

This hexagon pattern originates from the wave line 1 from point $\mathrm{A}$, line 2 from point $\mathrm{A}$, line 1 'from point $\mathrm{B}$, line 2 ' from point $\mathrm{B}$, the upper thickening line from the intersection of lines $1 \mathrm{~A}$ and 1 'B, and the lower thickening line from the confluence of lines $2 \mathrm{~A}$ and $2 \mathrm{~B}$. From the matrix, it can be shown that this 6 triangle is formed from 6 tangent wave lines in 1 box.

The symbolism of the symbols 7 and 2 making the degree of 72 or degree of 27 indicates constant in the universe. With 72 obtained Numbers 6 as balancing Numbers and 12 as super balancing Numbers. The combination of 3 balancing Numbers in 72 gives meaning to the allpowerful creator of the universe. Constant 12 can be found on the bottom of Borobudur. This number shows the worship symbol such as salat subuh as one with two salat jamak (dzuhur asar and magrib isa). Although Muslims have understood that the numbers of salat are 17 rakaat, but the numbers can be divide into two components. One is the component of salat without combining, and two are the components of salat with combining. One without combining is salat Subuh, and two with combining are salat dzuhur asar and salat magrib isa.

The presence of the number 72 is a transformation with the appearance of the number 19 in Covid-19 which is a continuation of the number from the Hahslm formula, namely 472319 where the fifth and sixth numbers are nineteen. It is no coincidence that the world is reminded to see evidence of the creation of a universe that has a constant of 72 and 19 in the Covid-19 era which has an impact on the global economic crisis [14].

Taking into account the significant impact of the pandemic both for life and for the economy, in the third emergency response period, namely July, the Yogyakarta Special Region Government gradually made efforts to encourage tourism in its region to grow again to suppress the prolonged economic impact. As published in (Yogyakarta's Efforts to Reopen the Tourism 
Sector, 2020), the DI Yogyakarta Government in July was still in the trial phase and carried out various simulations to ensure the readiness of tourist locations including hotels, restaurants, shopping places, and other supporting facilities. There is a team of verification and law enforcement that is tasked with assessing the readiness of supporting devices, especially in terms of implementing health protocols. In addition, education and outreach to the public, especially business actors in the tourism sector, are intensively carried out by utilizing outdoor media, television media, and social media.

Archeological activities are divided into low-risk archeological activities and high-risk archeological activities in the Covid-19 transmission. Economic with archeological activities that can be opened are mainly those related to nature, visitors that does not cause crowds, scientist that is more an approach to the ecosystem. Therefore, the prepared areas range from natural mountain visitors to national parks. This pandemic has an impact on changes in behavior and changes in the life order of people activities that will coexist with Corona so that the archeology sector enters a new life order concerning health, cleanliness, and security protocols [15].

\section{Conclusion}

The real owner of 72 stupas is Baka Queen as mentioned in Quran 3.96 with the word of Bakkah. There is one stupa left in Baka Queen Palace that is identical to what is in the top of Borobudur. The combination of Quran letter verse also strengthens to several stupas where $3+9 \times 6$ equals 72 stupas. This digit of seven and two shows the reflexivity of quantum physics in the form of wave interference. This is related to the 7 circular or hexagon-shaped superpositions that occur after passing 2 gaps. This constant of 72 was recorded on 72 Borobudur stupas. This upper level holds 72 stupas to show the monument of the quantum reality in the world of particles in the form of wave interference which is the boundary of modern physics. The constant 72 is also stored in the Quran with the formula 472319. The meaning of this 72 is that the straight path in the world is to worship the creator.

The name of Ratu Baka had come from local wisdom with the typical way of life and attitude of life. The only word that wrote in Quran is the name of Baka. After Ratu Baka stupas had been moved to Borobudur then people see the whole unity building in this place. Its foundation has 12 pair angles pairs that show constant worship or salat jamak (1 and 2). This area of a historical building can be grabbed the information of ancestors to have economic value while the pandemic situation due to exposure to Covid. Interference of worship in prayer is still being carried out despite the Covid-19 pandemic which has an impact on the global economic crisis.

\section{References}

[1] A. Soeroso and Y. S. Susuilo, "Strategi Konservasi Kebudayaan Lokal Yogyakarta," J. Manaj. Teor. dan Ter. J. Theory Appl. Manag., vol. 1, no. 2, 2008, doi: 10.20473/jmtt.v1i2.2363.

[2] C. F. Kreps, "On becoming 'museum-minded': A study of museum development and the politics of culture in Indonesia," ProQuest Diss. Theses, 1994.

[3] B. A. Potter, "Radiocarbon chronology of central Alaska: Technological continuity and economic change," Radiocarbon, vol. 50, no. 2, 2008, doi: 10.1017/S0033822200033518.

[4] H. Ahmad and B. G. Sigarete, "Preferensi Mahasiswa Dalam Berwisata: Studi Kasus Mahasiswa Sekolah Tinggi Pariwisata Ambarrukmo (STIPRAM), Yogyakarta," Kepariwisataan J. Ilm., vol. 12, 
no. 01, 2018, doi: 10.47256/kepariwisataan.v12i01.95.

[5] B. S. Nugraha, H. Mayandini, F. A. Putra, H. Madani, and N. Maulana, "Pendampingan Pengembangan Potensi Kampung Wisata Langenastran Menuju Sustainable Tourism Development," Kepariwisataan J. Ilm., vol. 11, no. 03, 2017, doi: 10.47256/kepariwisataan.v11i03.98.

[6] R. M. Aziz, "Integration of Islamic Mathematics in Quranic Equation and the Universe Creation," Pros. Semin. Nas. Integr. Mat. dan Nilai Islam., vol. 3, no. 1, 2020.

[7] M. Syaom Barliana Iskandar, "Tradisionalitas Dan Modernitas Tipologi Arsitektur Masjid," Dimens. (Jurnal Tek. Arsitektur), vol. 32, no. 2, 2004.

[8] A. Soeroso and Y. S. Susilo, "Traditional Indonesian Gastronomy As a Cultural Tourism Attraction," J. Appl. Econ. Dev. Ctries., vol. 1, no. 1, 2014.

[9] R. M. Aziz, "Hahslm Islamic Economics Methodology," ICoSEC (International Conf. Soc. Econ. Cult., 2018.

[10] M. A. de Perio, M. Kobayashi, and J. M. Wortham, "Occupational Respiratory Infections," Clinics in Chest Medicine, vol. 41, no. 4. 2020, doi: 10.1016/j.ccm.2020.08.003.

[11] F. Fredy, Y. Tembang, G. S. Bito, and O. H. Sholikhah, "Exploration Ethnomathematics of the Malind Tribe for Character Building in Elementary Schools," Int. J. Adv. Sci. Educ. Relig., vol. 3, no. 2, 2020, doi: 10.33648/ijoaser.v3i2.58.

[12] K. Wakasa and C. M. Wayman, "Crystallography and morphology of ferrous lath martensite," Metallography, vol. 14, no. 1, 1981, doi: 10.1016/0026-0800(81)90019-7.

[13] E. D. J. Smith, R. J. Blaikie, and D. P. Taylor, "performance enhancement of spectral-amplitudecoding optical CDMA using pulse-position modulation," IEEE Trans. Commun., vol. 46, no. 9, 1998, doi: $10.1109 / 26.718559$.

[14] R Mochamad A, "Rekam Medis Jantung Berpola Hahslm 472319 Dengan Ekonomi Covid,” 2021. [15] H. de Jonge, "Pilgrimages and Local Islam on Java," Stud. Islam., vol. 5, no. 2, 2014, doi: 10.15408/sdi.v5i2.751. 